\title{
Tensiones entre principios éticos y bioéticos para la atención integral de servicios en trasplantes
}

Tensions between ethical and bioethical principles for the integral attention of transplant services

\footnotetext{
Andrés Ávila Garavito'

Oncólogo clínico-trasplantes de médula ósea, Clínica de Oncología Astorga, Medellín (Colombia). Exmagistrado presidente del Tribunal de Ética Médica de Antioquia; miembro del Consejo Directivo de la Fundación Colombiana de Ética y Bioética; miembro del Comité Editorial de la Revista Colombiana de Hematología y Oncología.
}

Colombia es un país líder en trasplantes. El proceso educativo en salud ha logrado una madurez en la cultura de la donación de órganos y tejidos. Los pacientes en listas de espera son el problema principal y hace falta coordinar mayores esfuerzos para reducir las tasas de morbimortalidad en el grupo de candidatos por beneficiarse con curaciones. El número de trasplantes alogénicos de médula ósea se ha incrementado y se está realizando con mucho éxito en grupos de alto rendimiento, pero sigue siendo una cifra que no alcanza el $10 \%$ de los requeridos en nuestro país. Los pacientes adultos mayores se han podido beneficiar de nuevas técnicas y medicamentos con donantes no familiares, con resultados idénticos a los que se obtienen en mejores grupos de trabajo de países desarrollados.

Colombia es una nación que ha construido una cultura de trasplantes que contribuye a valorizar una genuina actividad de servicio y donación a los demás, sin claudicar en la labor primigenia de descubrir la verdad y de actuar bien. El servicio verdadero abre el diálogo auténtico, eficaz y pacífico; ayuda a remediar los lastres y limitaciones de la condición humana, anclados en la solidaridad y el amor que sana, mejora o salva la vida del otro. El gran prestigio académico de nuestros profesionales dedicados a todos los procesos complejos de trasplantes es fruto del esfuerzo de trabajo -coherente y comprometido- de sus equipos multidisciplinarios. Nuestro país también ha sido pionero en el mundo en las legislaciones, decretos y resoluciones sobre trasplantes. Aunque existe la presunción de donación en nuestro país, ayuda a la divulgación de una cultura de donación el carné donante en www. ins.gov.co. Sin duda, surgirán siempre obstáculos por superar en la prestación de todas las ventajas de estos programas, pero con creatividad y unidad cada paciente recibirá la mejor tecnología con los recursos disponibles en nuestro medio. Para lograr una mayor eficiencia y eficacia en la articulación de la red nacional, todos los actores sociales, privados o públicos, asociaciones de pacientes y universidades deben trabajar en apoyar sin condiciones las necesidades y expectativas de cada programa. Se requiere una "continua reflexión ética y bioética, nunca agotada sobre la grandeza y dignidad de la persona humana" -Tribunal de Ética Médica de Antioquia (TEMA). Vol. 1. $2^{\text {a }}$ ed. Medellín: DSSA, Gobernación de Antioquia; 2013. Contraportada-.

Sí, existen tensiones entre principios éticos en los programas de trasplantes con implicaciones prácticas en dilemas entre expertos y dolientes. La ausencia de conflictos de interés en los grupos de alto rendimiento, la protección de los derechos y deberes del donante y el receptor, de las minorías y los grupos étnicos son reflejo de compromisos éticos y bioéticos en los difíciles escenarios de tomas de decisiones que ponderan con acierto los dilemas concretos. Quien sigue la huella de una conciencia bien formada tiene una sabiduría prudencial que le ayuda a ponderar que no todo lo que se puede hacer se debe hacer. Toda persona sana está llena de dilemas y conflictos, y no nos pasa absolutamente nada si perdemos el miedo a resolver esas tensiones. Es saludable pasar vergüenza de las misiones no cumplidas y de omisiones graves o leves. Hay que huir de las rutinas y abrir espacios propositivos, analizando a fondo hechos relevantes, con aportes de soluciones 
claras, sencillas y estructuradas. Son tiempos nuevos para acrecentar la confianza y la credibilidad, superar las improvisaciones y lograr un enfoque integrador, basado en las verdaderas necesidades del paciente y su familia. Realmente, el paciente es la médula de los trasplantes. Todos soñamos con pacientes sanos hasta la médula ósea. Estos modelos de trabajo en equipo son signo de una cultura integradora de saberes para beneficiar al más necesitado. El debate nunca lleva a una pelea, sino a un acuerdo, así sea que se esté en desacuerdo. Nadie debe rehuir el imperativo que une a los grupos de trabajo. No es opción que cada uno vaya por su lado, porque cada uno debe ser un buen profesional y todos profesionales buenos. En medicina, no cabe siquiera plantearse otro objetivo que el bien del paciente sano o enfermo.

El Instituto Nacional de Cancerología en Bogotá ha tenido una alta influencia en la difusión de documentos técnicos en diferentes modelos de atención para el paciente oncológico. Esas bases teóricas son plataformas para el desarrollo de programas, reflexiones para quienes legislan y auditan programas de trasplantes, en iniciativas replicadoras que requieren de una sólida educación continua para modelos técnicos, humanos y bioéticos de los grupos de trabajo. El artículo 30, "Del programa de estímulos e incentivos", obligó al gobierno nacional a definir un programa de estímulos e incentivos dirigido al personal de la salud, con varios objetivos, entre ellos el generar programas de apoyo a la calidad en la formación de personal y la prestación de servicios (Colombia, Congreso de la República. Ley 1164 de 2007, Talento Humano en Salud. ).

Cada equipo tratante se renueva mediante un soporte formativo específico y merece todo tipo de esfuerzos, internos y externos para mantenerlo unido. El sentido de su quehacer solidario, compasivo y con detalles de servicio le permite mantener un estado de ánimo y de vitalidad que motiva al paciente y su entorno, y al mismo grupo de trabajo, que no se cansa ni cansa con un trabajo bien hecho. Estos documentos facilitan la creación de un lenguaje propio en cada región y microcultura de nuestro país, la participación ciudadana y la labor de expertos en ciencias sociales y de la familia: pedagogos, educadores en salud, líderes comunales, antropólogos y comunicadores. Para los grupos de trasplantes, es necesario el acompañamiento de un experto en ética por tensiones entre principios: autonomía y reciprocidad; solidaridad y justicia, etc. La educación en principios éticos es la mejor medicina. El bien que debemos difundir en nuestro obrar ético es infinito y fecundo -Tribunal Ética Médica de Antioquia (TEMA). Vol. 2. $1^{\text {a }}$ ed. Medellín: DSSA, Gobernación de Antioquia; 2013. p. 123-.

En un mundo complejo y de cambios acelerados, las posibles soluciones han de ser esencialmente colectivas. No son fruto de un plan de pocos, sino de la acción de muchas personas, a todos los niveles, que se adaptan y modifican modelos mentales para enfrentarse a una nueva realidad de cambios rápidos. Hoy día se requiere de un liderazgo diferente, colaborativo, interactivo y transversal. El cambio constante es agotador y demanda encontrar energías para todos los miembros del equipo de trabajo. Este nuevo liderazgo no limita ni tiene fronteras; persuade a otros para construir y compartir valor en la comunidad; genera empatía y confianza entre las personas, facilitando el trabajo en redes colaborativas. El nuevo líder lucha por ser una persona íntegra, regalándose con sencillez y alegría; domina competencias claves, influye con naturalidad, sin manipulaciones y se adapta para desarrollar nuevas competencias y formas de hacer colaborativas. El orgullo y el prejuicio son siempre obstáculos para el sentido, la sensatez y la sensibilidad de un líder. Todos podemos ejercer un liderazgo verdadero que reivindique la primacía de la bondad. Es más trascendental ser bondadoso que sabio, y entender esto es el principio de la sabiduría. El viejo quehacer de jerarquía prepotente está fracasando y ha dado paso a un liderazgo de redarquía como estructura natural para la innovación y el ajuste a las nuevas circunstancias. Sin temor ni complejos podemos hacer nuestro lo dicho por Ludwig van Beethoven: "No conozco ningún otro signo de superioridad que la bondad". ¡Qué bien le suenan a un genio de la música esas verdades!

En concordancia con los postulados de la Revista Colombiana de Hematología y Oncología, las investigaciones y publicaciones en esta edición reflejan el liderazgo colaborativo de sus autores, mediante modelos y procesos completos, que difunden sus experiencias, sus resultados en la investigación académica, su actividad docente y su proyección social, a través de artículos originales, ensayos, informes y demás trabajos orientados al beneficio de los pacientes, destacando el compromiso científico y académico para el bien de las generaciones futuras. 